Science and Tecnology

\title{
Agroekologi : Model Pertanian Berkelanjutan Masa Depan
}

\author{
Kiki Yulianto \\ Email: kikiyulianto87@gmail.com
}

Fakultas Teknologi Pertanian, Universitas Teknologi Sumbawa

\section{PENDAHULUAN}

\subsection{Latar Belakang}

Indonesia sebagai negara kepulauan yang terletak di daerah khatulistiwa termasuk wilayah yang sangat rentan terhadap perubahan iklim. Perubahan pola curah hujan, kenaikan muka air laut, dan suhu udara, serta peningkatan kejadian iklim ekstrim berupa banjir dan kekeringan merupakan beberapa dampak serius perubahan iklim yang dihadapi Indonesia.

Perubahan iklim akan menyebabkan: (a) seluruh wilayah Indonesia mengalami kenaikan suhu udara, dengan laju yang lebih rendah dibanding wilayah subtropis; (b) wilayah selatan Indonesia mengalami penurunan curah hujan, sedangkan wilayah utara akan mengalami peningkatan curah hujan. Perubahan pola hujan tersebut menyebabkan berubahnya awal dan panjang musim hujan. Di wilayah Indonesia bagian selatan, musim hujan yang makin pendek akan menyulitkan upaya meningkatkan indeks pertanaman (IP) apabila tidak tersedia varietas yang berumur lebih pendek dan tanpa rehabilitasi jaringanirigasi. Meningkatnya hujan pada musim hujan menyebabkan tingginya frekuensi kejadian banjir, sedangkan menurunnya hujan pada musim kemarau akan meningkatkan risiko kekekeringan. Sebaliknya, di wilayah Indonesia bagian utara, meningkatnya hujan pada musim hujan akan meningkatkan peluang indeks penanaman, namun kondisi lahan tidak sebaik di Jawa. Trend perubahan ini tentunya sangat berkaitan dengan sektor pertanian.

Perpaduan antara meningkatnya suhu rata-rata, siklus hidrologi yang terganggu sehingga menyebabkan musim kemarau lebih panjang dan musim hujan yang lebih intensif namun lebih pendek, meningkatnya siklus anomali musim kering dan hujan dan berkurangnya kelembaban tanah akan menganggu sektor pertanian.

\subsection{Perumusan Masalah}

Fenomena pemanasan global telah memberikan dampak pada berubahnya tatanan iklim dunia yang saat ini telah kita rasakan dampaknya secara global. Perubahan iklim global (global climate change) telah memberikan dampak nyata disemua sisi kehidupan masyarakat di Indonesia dan di dunia pada umumnya. Setahun terakhir banyak sekali petani yang mengalami gagal panen dan nelayan tidak melaut akibat kondisi iklim dan cuaca yang tidak menentu. Jadwal dan pola tanampun mengalami perubahan.

Sektor pertanian perlu beradaptasi terhadap perubahan iklim karena seiring dengan semakin tingginya suhu bumi dan berubahnya pola presipitasi terjadi juga: perubahan zona iklim dan pertanian, perubahan pola produksi pertanian, makin meningkatnya produktivitas karena pertambahan $\mathrm{CO}_{2}$ di atmosfer dan bertambahnya kerentanan orang-orang yang tidak memiliki tanah dan miskin.

Perubahan iklim akan mempengaruhi hasil panen yang kemungkinan besar akan berkurang disebabkan oleh semakin keringnya lahan akibat musim kemarau yang lebih panjang. Pada skala yang ekstrem, berkurangnya hasil panen dapat mengancam ketahanan pangan. Selain itu, kebutuhan irigasi pertanian juga akan semakin meningkat namun disaat yang sama terjadi kekurangan air bersih karena mencairnya es di kutub yang menyebabkan berkurangnya cadangan air bersih dunia. Hal ini dapat berujung pada kegagalan panen berkepanjangan yang juga menyebabkan pasokan pangan menjadi sangat tidak pasti. 
Curah hujan di beberapa wilayah di Indonesia diprediksikan akan meningkat sekitar 2-3\%/tahun. Di Jawa, Bali, NTB, NTT, sebagian Sulawesi, Maluku dan Papua curah hujan akan berkurang. Kecenderungan yang akan terjadi adalah musim kemarau lebih panjang. Khusus di Pulau Jawa, perubahan musim akan sangat ekstrem dimana musim hujan akan menjadi sangat basah dan musim kering akan menjadi sangat kering dan lebih panjang. Hal ini menyebabkan Jawa menjadi rawan banjir dan kekeringan. (BMKG, 2009).

Dampak perubahan iklim terhadap Indonesia dapat positif maupun negatif. Di beberapa daerah, konsentrasi $\mathrm{CO}_{2} \mathrm{di}$ atmosfer dan radiasi matahari dapat berakibat positif untuk proses fotosintesis. Pemanasan global menyebabkan penurunan hasil panen di Jawa Barat dan Jawa Timur. Sementara konsentrasi $\mathrm{CO}_{2}$ yang dilipat gandakan akan mempengaruhi hasil panen di benua Asia antara -22\% hingga $+28 \%$ pada tahun 2100 (Reilley, 1996 dalam PEACE, 2007).

Konsep pembangunan berkelanjutan sebenarnya sudah lama menjadi perhatian para ahli. Namun istilah keberlajutan (sustainability) sendiri baru muncul sejak beberapa dekade yang lalu, walaupun perhatian terhadap keberlanjutan sudah dimulai sejak Malthus pada tahun 1798. Tujuan pembangunan pada hakekatnya adalah untuk meningkatkan kesejahteraan dan kemakmuran masyarakat. Sedangkan Pembangunan berkelanjutan adalah pembangunan yang memenuhi kebutuhan generasi saat ini tanpa mengurangi kemampuan generasi mendatang untuk memenuhi kebutuhan mereka. Untuk mencapai tujuan tersebut dibutuhkan strategi pelaksanaannya, diantaranya ada empat hal yang perlu diperhatikan yaitu; pemerataan, partisipasi, keanekaragaman, integrasi, dan perspektif jangka panjang yang diikuti pendekatan secara ideal. Pembangunan berkelanjutan mencakup berbagai aspek kehidupan yaitu; keberlanjutan ekologis, ekonomi, sosial budaya, politik, serta pertahanan dan keamanan.

Pertanian berkelanjutan adalah sebagai upaya manusia untuk memperbaiki mutu kehidupan dengan tetap berusaha tidak melampaui ekosistem yang mendukung kehidupannya. Dewasa ini masalah pertanian berkelanjutan telah dijadikan sebagai isu penting yang perlu terus di sosialisasikan ditengah masyarakat. Oleh karena itu penulis merasa tertarik untuk mengurai permasalahan pertanian berkelanjutan yang terkait hubungan dengan perubahan iklim yang terjadi di bumi ini.

\subsection{Tujuan Penulisan}

Tujuan penulisan adalah menyajikan model pertanian berkelanjutan dalam menghadapi pengaruh perubahan iklim dan memberikan informasi dalam mendukung pelaksanaan pembangunan pertanian.

\section{URAIAN}

\subsection{Perubahan Iklim Global}

Perubahan iklim dengan segala penyebabnya secara faktual sudah terjadi di tingkat lokal, regional maupun global. Peningkatan emisi dan konsentrasi gas rumah kaca (GRK) mengakibatkan terjadinya pemanasan global, diikuti dengan naiknya tinggi permukaan air laut akibat pemuaian dan pencairan es di wilayah kutub.

Naiknya tinggi permukaan air laut akan meningkatkan energi yang tersimpan dalam atmosfer, sehingga mendorong terjadinya perubahan iklim, antara lain $E l$ Nino dan La Nina. Fenomena El Nino dan La Nina sangat berpengaruh terhadap kondisi cuaca/iklim di wilayah Indonesia dengan geografis kepulauan. Sirkulasi antara benua Asia dan Australia serta Samudera Pasifik dan Atlantik sangat berpengaruh, sehingga wilayah Indonesia sangat rentan terhadap dampak dari perubahan iklim. Hal ini diindikasikan dengan terjadinya berbagai peristiwa bencana alam yang intensitas dan frekuensinya terus meningkat.

Fenomena El Nino adalah naiknya suhu di Samudera Pasifik hingga menjadi $31^{\circ} \mathrm{C}$, sehingga akan menyebabkan kekeringan yang luar biasa di Indonesia. Dampak negatifnya antara lain adalah peningkatan frekuensi dan luas kebakaran hutan, kegagalan panen, dan penurunan ketersediaan air. Fenomena La Nina merupakan kebalikan dari El Nino, yaitu gejala menurunnya suhu permukaan 
Samudera Pasifik, yang menyebabkan angin serta awan hujan ke Australia dan Asia Bagian Selatan, termasuk Indonesia. Akibatnya, curah hujan tinggi disertai dengan angin topan dan berdampak pada terjadinya bencana banjir dan longsor besar.

Perubahan iklim sudah berdampak pada berbagai aspek kehidupan dan sektor pembangunan di Indonesia. Sektor kesehatan manusia, infrastruktur, pesisir dan sektor lain yang terkait dengan ketersediaan pangan (pertanian, kehutanan dan lainnya) telah mengalami dampak perubahan tersebut.

Di sektor pertanian, sama dengan sektor lainnya, belum ada studi tingkat nasional yang mengkaji dampak perubahan iklim terhadap sumber daya iklim, lahan, dan sistem produksi pertanian (terutama pangan). Beberapa studi masih dilakukan pada tingkat lokal, seperti pengkajian dampak perubahan iklim pada hasil padi dengan menggunakan model simulasi. Kerentanan suatu daerah terhadap perubahan iklim atau tingkat ketahanan dan kemampuan beradaptasi terhadap dampak perubahan iklim, bergantung pada struktur sosial-ekonomi, besarnya dampak yang timbul, infrastruktur, dan teknologi yang tersedia. Di Indonesia, upaya-upaya mitigasi dan adaptasi perubahan iklim sebenarnya telah dimulai sejak tahun 1990, walaupun Indonesia tidak memiliki kewajiban untuk memenuhi target penurunan emisi GRK. Untuk memperkuat pelaksanaan mitigasi dan adaptasi perubahan iklim di Indonesia pada sektor pertanian, perlu ditetapkan strategi nasional mitigasi dan adaptasi perubahan iklim secara ter integrasi, yang melibatkan berbagai instansi terkait

\subsection{Strategi Antisipasi}

Perlunya pemahaman yang baik terhadap fenomena dan dampak perubahan iklim global pada sektor pertanian dan strategi antisipasi yang harus dilakukan. Untuk itu, hasil kegiatan penelitian/ pengkajian dan adaptasi yang telah dilakukan oleh lembaga-lembaga penelitian perlu diinventarisasi untuk dirumuskan dan disosialisasikan ke berbagai kalangan. Perlu penelitian/pengkajian yang lebih komprehensif dan intensif terhadap komponen sumber daya, infrastruktur, dan sub sektor pertanian, serta daerah-daerah rawan atau yang telah terkena dampak perubahan iklim, serta adaptasi yang telah, sedang dan akan diterapkan. Dalam menghadapi dan menanggulangi dampak perubahan iklim, terutama kekeringan dan banjir perlu adanya (a) Standard Operating Procedure (SOP) tentang informasi perubahan iklim serta mekanisme penyampaiannya ke pengguna terutama petani, dan (b) Sekolah Lapang Pertanian (SLP) yang terintegrasi untuk berbagai aspek seperti pengelolaan informasi iklim/air, pengendalian hama terpadu, agribisnis, dan lain-lain. Strategi Antisipasi dampak Perubahan Iklim Terhadap Sektor Pertanian adalah dengan : (a) menggalang komunikasi di antara Lembaga Penelitian/ Perguruan Tinggi, baik nasional maupun internasional, (b) mengintegrasikan dan mensinergikan kegiatan-kegiatan penelitian yang berkaitan dengan perubahan iklim, dan (c) melaksanakan penelitian secara terintegrasi yang melibatkan berbagai lembaga penelitian dan perguruan tinggi.

Program penelitian ditujukan pada pengkajian/analisis dampak biofisik (sumber daya, infrastruktur/ sarana, sistem produksi dan aspek social ekonomi), konsep strategi antisipasi, mitigasi dan penanggulangan (adaptasi teknologi), dan membangun kemampuan prediksi dan penyampaian informasi. Kegiatan yang berkaitan dengan perakitan teknologi, terutama varietas unggul, akan dikaitkan dengan program penelitian balai penelitian komoditas.

Penyusunan dan penyampaian hasil prakiraan musim yang menjadi otoritas BMG perlu dilakukan lebih sering dan cepat, minimal 4 kali setahun. Hasil prakiraan tersebut perlu diformulasikan oleh Pokja Anomali Iklim dan Badan Litbang Pertanian, agar menjadi informasi yang lebih aplikatif dan mudah dipahami penyuluh dan petani. Selanjutnya, informasi matang tersebut perlu segera disampaikan kepada masyarakat pertanian agar kegiatan adaptasi pertanian dapat segera dilakukan. Selain melakukan adaptasi dan mitigasi perubahan iklim, diperlukan upaya untuk memanfaatkan perubahan iklim tersebut, 
agar menjadi sahabat dalam sektor pertanian.

\subsection{Agroekologi1 Ramah Lingkungan : Model Pertanian Berkelanjutan Masa Depan}

Perubahan iklim akan mempengaruhi produktivitas pertanian dan kesejahteraan manusia. Secara keseluruhan, diperkirakan bahwa produktivitas tanaman akan menurun pada garis terendah, terutama di musim kering dan daerah-daerah tropis. Hal ini akan meningkatkan risiko kelaparan. Selain itu, mayoritas pedesaan miskin di dunia yang tinggal di daerah-daerah miskin sumberdaya, sangat heterogen dan rawan risiko yang akan paling terpukul oleh perubahan iklim

Di sisi lain, pertanian melepaskan sebagian besar karbondioksida, metana dan nitroksida ke atmosfer, yang berjumlah sekitar 10-12 persen emisi gas rumah kaca anthropogenik global setiap tahunnya. Jika kontribusi tidak langsung (misalnya konversi lahan, produksi dan distribusi pupuk dan operasi pertanian) ikut dihitung, kontribusi pertanian dapat setinggi 17-32 persen emisi anthropogenik ${ }^{2}$ global.

Tantangannya adalah merancang pertanian yang dapat menyesuaikan dan merespon perubahan iklim, serta mengurangi emisi gas rumah kaca. Tantangan ini dapat dipenuhi melalui keragaman hayati, pertanian berbasis agroekologi.

Hal ini diakui oleh Kajian International tentang Pertanian, Ilmu Pengetahuan dan Teknologi untuk Pembangunan (International Assessment on Agricultural Knowledge, Science and Technology for Development - IAASTD), yang merupakan penilaian pertanian paling komprehensif saat ini. Beberapa temuan kunci dari IAASTD ${ }^{3}$ adalah:

\footnotetext{
${ }^{1}$ Agroekologi adalah ilmu pengetahuan dalam pertanian berkelanjutan atau ekologis

${ }^{2}$ Antropogenik adalah segala sesuatu yang disebabkan oleh manusia

${ }^{3}$ IAASTD adalah kajian multistakeholder meliputi lebih dari 400 ahli dengan periode lebih dari empat tahun, dan didukung oleh Bank Dunia (World Bank), FAO, UNEP, UNDP, WHO, UNESCO and GEF.
}

1. Pertanian masa depan terletak pada keragaman hayati, pertanian berbasis agroekologi (termasuk pertanian organik) yang dapat memenuhi tujuan sosial, ekonomi dan lingkungan.

2. Ketergantungan pada sumberdaya ekstraktif pertanian industri adalah tidak berkelanjutan, terutama dalam menghadapi iklim yang memburuk, krisis energi dan air.

3. Teknis perbaikan jangka pendek, termasuk tanaman rekayasa genetik, tidak dapat mengatasi kompleksnya tantangan yang dihadapi pertanian, dan seringkali memperburuk kerugian sosial dan lingkungan.

4. Pencapaian ketahanan pangan dan mata pencaharian yang berkelanjutan memerlukan jaminan akses dan kontrol sumberdaya oleh petani skala kecil, khususnya perempuan.

5. Pengetahuan tradisional dan inovasi berbasis masyarakat adalah bagian tak ternilai dari solusi.

Dengan meningkatkan ketahanan dalam agroekosistem, agroekologi dapat meningkatkan kemampuan untuk terus berfungsi ketika berhadapan dengan kejadian tak terduga seperti perubahan iklim. Ketahanan terhadap bencana iklim berhubungan erat dengan keragaman hayati pertanian; praktik-praktik yang meningkatkan keragaman hayati pertanian memungkinkan untuk meniru prosesproses ekologi alami, sehingga memungkinkan mereka menanggapi perubahan dan mengurangi risiko dengan lebih baik.

Dengan demikian, petani yang meningkatkan keragaman antar spesies, kurang mengalami dampak kerusakan dibandingkan dengan petani konvensional yang menanam secara monokultur. Selain itu, penggunaan keragaman intraspesifik (tanaman yang sama dengan kultivar berbeda) adalah perlindungan terhadap perubahan lingkungan di masa depan.

Praktik-praktik agroekologi yang melestarikan kesuburan tanah dan memelihara atau meningkatkan bahan organik dapat mengurangi efek negatif dari 
kekeringan disamping meningkatkan produktivitas. Kemampuan menahan air tanah diperkuat dengan praktik-praktik yang membangun materi organik, sekaligus membantu petani menghadapi kekeringan. Selain itu, praktik-praktik penampungan air memudahkan petani mengandalkan cadangan air selama musim kemarau. Praktik-praktik lain seperti penyimpanan sisa hasil tanam, jerami, dan agroforestry, menjaga kelembaban tanah dan melindungi tanaman terhadap iklim mikro ekstrem. Selain itu, bahan organik juga meningkatkan penangkapan air dalam tanah, sehingga secara signifikan mengurangi risiko banjir.

Pengetahuan adat dan tradisional adalah sumber informasi utama tentang kemampuan adaptasi, seleksi terpusat, eksperimental dan kemampuan tangguh petani. Banyak petani mengatasi perubahan iklim dalam berbagai cara, seperti mengurangi kegagalan panen melalui peningkatan penggunaan varietas lokal tahan kekeringan, pemanenan air, penanaman ekstensif, tanaman campuran, agroforestri, penyiangan yang terpilih dan pengumpulan tanaman liar. Pengetahuan tradisional, ditambah dengan investasi yang tepat dalam pembibitan tanaman, bisa menghasilkan varietas baru dengan potensi adaptasi iklim.

Di sisi lain, pertanian memiliki potensi untuk berubah dari salah satu penyumbang emisi gas rumah kaca terbesar menjadi lebih kecil dan bahkan bisa menjadi penyerap karbon, selain menawarkan pilihan untuk mitigasi dengan mengurangi emisi dan penyerapan karbondioksida dari atmosfer ke dalam tanah. Solusinya adalah menyerukan perubahan menuju praktikpraktik pertanian berkelanjutan yang membangun karbon dalam tanah dan menggunakan lebih sedikit pupuk dan pestisida kimia.

Ada bermacam praktik-praktik yang dapat mengurangi kontribusi sektor pertanian terhadap perubahan iklim. Ini termasuk rotasi tanaman dan peningkatan desain sistem pertanian, perbaikan pengolaan penanaman, peningkatan pengelolaan nutrisi dan pupuk kandang, peningkatan lahan untuk merumput dan pengelolaan ternak, mempertahankan kesuburan tanah dan pemulihan lahan rusak, perbaikan pengelolaan air dan padi, pengelolaan pemupukan, perubahan pemanfaatan lahan dan agroforestry.

Diperkirakan bahwa konversi menuju pertanian organik akan meningkatkan penyerapan karbondioksida melalui penggunaan teknik-teknik yang membangun materi organik tanah, serta mengurangi emisi nitroksida hingga duapertiga karena tidak ada input nitrogen mineral eksternal dan lebih efisien penggunaan nitrogen. Sistem organik telah menemukan cara untuk menyimpan lebih banyak karbondioksida daripada pertanian konvensional, sedangkan teknik yang mengurangi erosi tanah dapat mengkonversi kehilangan karbon menjadi keuntungan. Pertanian organik juga mandiri dalam nitrogen karena daur ulang pupuk kandang dari ternak dan residu tanaman melalui pembuatan kompos, serta penanaman tanaman polong-polongan.

\section{SIMPULAN}

Indonesia sebagai negara kepulauan yang terletak di daerah khatulistiwa termasuk wilayah yang sangat rentan terhadap perubahan iklim. Perubahan pola curah hujan, kenaikan muka air laut, dan suhu udara, serta peningkatan kejadian iklim ekstrim berupa banjir dan kekeringan merupakan beberapa dampak serius perubahan iklim yang dihadapi Indonesia.

Fenomena pemanasan global telah memberikan dampak pada berubahnya tatanan iklim dunia yang saat ini telah kita rasakan dampaknya secara global. Perubahan iklim global (global climate change) telah memberikan dampak nyata disemua sisi kehidupan masyarakat di Indonesia dan di dunia pada umumnya. Setahun terakhir banyak sekali petani yang mengalami gagal panen akibat kondisi iklim dan cuaca yang tidak menentu. Jadwal dan pola tanampun mengalami perubahan.

Dalam strategi untuk mengatasi pengaruh perubahan iklim terhadap pertanian berkelanjutan, maka diperlukan langkah-langkah yaitu :

1. Merancang pertanian yang dapat menyesuaikan dan merespon perubahan iklim, serta mengurangi emisi gas rumah kaca. Tantangan ini 
dapat dipenuhi melalui keragaman hayati, pertanian berbasis agroekologi.

2. Studi tingkat nasional yang mengkaji dampak perubahan iklim terhadap sumber daya iklim, lahan, dan sistem produksi pertanian (terutama pangan).

3. Penelitian/pengkajian yang lebih komprehensif dan intensif terhadap komponen sumber daya, infrastruktur, dan sub sektor pertanian, serta daerah-daerah rawan atau yang telah terkena dampak perubahan iklim, serta adaptasi yang telah, sedang dan akan diterapkan.

4. Praktik-praktik agroekologi yang melestarikan kesuburan tanah dan memelihara atau meningkatkan bahan organik dapat mengurangi efek negatif dari kekeringan disamping meningkatkan produktivitas.

\section{DAFTAR PUSTAKA}

Anonim. 2008. Dampak perubahan iklim terhadap sektor pertanian, serta strategi antisipasi dan teknologi adaptasi. BBPPSLP, Bogor.

Anonim. 2010. Pertanian seperti apa yang kita butuhkan di era perubahan iklim. www.wfu.com diakses tanggal 09 Desember 2010.

BMKG. 2009. Tren Perubahan Iklim dan Dampaknya bagi Indonesia: Perspektif dari Model dan Kajian Ilmiah Terbaru. Presentasi pada FGD tentang Adaptasi, DNPI, Jakarta.

Maulidia, Martha. 2010. Dampak perubahan iklim terhadap pertanian. www.iklimkarbon.com diakses tanggal 09 Desember 2010.

PEACE. 2007. Indonesia and Climate Change: Current Status and Policies. World Bank, Jakarta. 